\title{
KEBERADAAN WACANA PANTANG LARANG BERLARAS GENDER SEBAGAI TRADISI LISAN, FENOMENA BAHASA, DAN SASTRA LISAN DI INDONESIA
}

\author{
Gatot Sarmidi \\ Universitas Kanjuruhan Malang, Stonetitogats@yahoo.co.id \\ Turen Permai H18 Talangsuko Turen, Hp 081334509467
}

\begin{abstract}
Abstrak
Pantang larang atu lebih dikenal dengan istilah pamali dalam beberapa istilah daerah merupakan salah satu jenis ungkapan bersifat larangan baik dituturkan langsung atau tidak langsung. Fenomena yang muncul dari pantang larang adalah keberadaannya sebagai tradisi lisan yang membutuhkan eksplanasi ilmiah. Terkait dengan fenomena tersebut, tulisan ini bertujuan mendeskripsikan dan memberikan penjelasan ilmiah terhadap keberadaan pantang larang yang diambil dari beberapa fenomena yang ada di Indonesia. Walaupun kajiannya tidak mendalam, dengan metode deskriptif kualitatif, penelitian yang dihasilkan dan disampaikan dalam tulisan ini diharapkan dapat memberikan contoh penjelasan salah satu bentuk wacana bahkan salah satu genre teks, yakni pantang larang berlaras gender yang dalam tulisan ini dijelaskan secara interdisipliner dalam keberadaannya sebagai tradisi lisan, fenomena bahasa, dan sastra lisan di Indonesia.
\end{abstract}

Kata-kata Kunci: pantang larang, tradisi lisan, fenomena bahasa, sastra lisan Indonesia

Pantang larang merupakan bagian dari tradisi lisan. Amir (2013:4) menjelaskan bahwa kegiatan hidup dalam masyarakat tidak hanya sastra dan seni, tetapi juga pertuturan adat, mantera, lagu permainan anak-anak, bahkan lagu-lagu pujian bagi orang baru meninggal, atau dendang untuk orang yang mau menangkap harimau, binatang buas, binatang, dan paling umum, yaitu percakapan antaranggota masyarakat. Sementara itu, Ningsih (2013:371) menjelaskan bahwa yang dimaksud pantang larang adalah perbuatan atau perilaku yang pantang atau dilarang untuk dilakukan. Ada juga yang menyebutkan tabu untuk dilakukan. Apabila seseorang melakukan pantang larang akan menerima akibat buruk dan menakutkan, misalnya ibu atau bapaknya meninggal, jatuh miskin, atau binatang piaraannya mati. Akibat buruk yang ringan adalah dijauhi oleh masyarakat.

Pantang larang atau pamali merupakan makna larangan yang diungkapkan oleh orangorang terdahulu dalam kondisi masyarakat yang masih mitis. Ungkapan lisan berpola yang hadir secara turun-temurun itu sering di dengar dari para orang tua, misalnya kakek atau nenek masing-masing. Bisa ditafsirkan pantangan-pantangan atau larangan-larangan disampaikan oleh para generasi pendahulu menjadi suatu kata-kata bijak yang berisi kearifan lokal. Tentu saja, ungkapan-ungkapan dalam wujud kata-kata atau kalimat berpola yang berisi pantangan atau larangan itu berawal dari sejumlah kasus baik yang terselesaikan karena dapat dinalar keberadaannya maupun yang cukup diterima karena dipercaya begitu saja, diturunkan antargenerasi dalam beberapa situasi tanpa penalaran yang jelas.

Segala sesuatu terjadi karena kehendak Tuhan. Tetapi, sebagai sebuah ung-kapan yang didasarkan pada mitos, legenda, atau peristiwa-peristiwa yang dianggap ganjil sebagaimana disebutkan sebagai ungkapan pantang larang atau pamali merupakan fenomena bahasa bahkan disikapi sebagai genre sastra lisan di Indonesia. Begitulah uniknya tradisi lisan negeri ini, misalnya pantang larang untuk anak-anak tidak boleh makan berpindah-pindah tempat nanti akan mendapatkan ibu tiri, tidak boleh tidur berselimut tikar nanti akan digulung ombak, 
tidak boleh berteriak-teriak dalam hutan khawatir dimasuki roh halus atau akan kesurupan.

Sebagian masyarakat, ungkapan pantang larang dianggap mitos. Mitos dipercaya sebagai ajaran nenek moyang tentang apa yang tidak boleh dilakukan agar tidak tertimpa daerah. Di beberapa daerah ungkapan semacam ungkapan pantang larang, terutama di pedesaan masih banyak yang mempercayai mitos walaupun secara logika tidak masuk akal. Berikut contoh pantang larang dan penjelasan yang sekirannya mendekatkan sehingga ada rasionalitas bahwa pantang larang itu menjadi masuk akal. Beberapa mitos yang populer di Indonesia, di antaranya: (1) Kalau malam tiba dilarang berdiri di bawah pohon agar tidak dibius setan, (2) Jangan memakai payung pada makan hari tanpa alasan, (3) Wanita tidak boleh duduk di depan pintu, (4) Jangan bersiul pada malam hari, (5) Tertimpa cicak tandanya sial, Memakai payung di dalam rumah berarti sial, Jangan memakai sesuatu yang tajam di malam hari, pamali

Tujuh contoh teks pantang larang di atas merupakan contoh teks pantang larang yang akrab, sering muncul, dan dikenal di Indonesia. Maksudnya ungkapan pantang larang itu tidak asing di telinga sebagian besar masyarakat. Tujuh contoh pantang larang itu, tampaknya mudah diterima karena mudah dijelaskan maksud atau implikasi makna yang diterima oleh peserta tutur ketika ungkapan pantang larang muncul dari mulut pembicara. Sebagaimana data 1 Kalau malam tiba dilarang berdiri di bawah pohon agar tidak dibius setan, penjelasannya seseorang bisa saja pingsan pada saat berada di bawah pohon besar di malam hari. Kejadian ini tidak ada hubungannya sama sekali dengan dibius setan. Pada siang hari tumbuhan membutuhkan karbondioksida untuk bernafas, tetapi pada malan hari tumbuhan membutuhkan oksigen untuk bernafas. Manusia memerlukan oksigen untuk bernafas, jadi proses pernafasan manusia akan terganggu ketika berada di bawah pohon pada malam hari. Pada data 2 jangan memakai payung pada makan hari tanpa alasan, penjelasannya jelas tidak disarankan, jika Anda melakukannya pasti akan disangka orang gila. Tidak panas tidak hujan tetapi memakai payung. Pada data 3 wanita tidak boleh duduk di depan pintu, penjelasannya bahwa pada zaman dahulu wanita masih menggunakan rok, belum ada yang memakai celana. Jadi, kalau ada wanita yang duduk di depan pintu pasti akan terlihat...ya gitu deh. Pasti banyak mengundang hawa nafsu. Pada data 4 jangan bersiul pada malam hari, maksudnya adalah agar tidak mengganggu orang - orang yang sedang tidur. Pada data 4 memakai payung di dalam rumah berarti sial, dijelaskan secara lisan ya sial kalau lagi ada banyak orang di dalam rumah dan kita memakai payung. Mungkin orang - orang di sekitar Anda akan merasa terganggu atau tercolok matanya. Pada data 5 tertimpa cicak tandanya sial, dijelaskan bahwa sial di sini maksudnya dari tertimpa cicak itu sendiri. Siapa yang tidak sial kalau sedang enak - enak duduk tiba - tiba tertimpa cicak. Pada data 6 jangan memakai sesuatu yang tajam di malam hari, pamali. Penjelasannya, mungkin mitos ini muncul sebelum adanya listrik, jadi rasa orang tua melarang anaknya untuk tidak menggunakan benda tajam di malam hari. Kalau sekarang kan sudah ada listrik, buat apa mempercayai mitos ini. Demikian penjelasan masuk akal dari mitos 7 mitos terpopuler di Indonesia. Para nenek moyang menganggapnya sebagai pamali atau ora ilok kalau orang Jawa bilang. Sebagai orang yang beragama, khususnya Islam tidak boleh mempercayai ramalan atau semacamnya karena hidup dan mati berada di tangan Tuhan, bukan nenek moyang.

Apapun tidak larangan tidak lepas dari tradisi kekuasaan. Dalam budaya patriarki ada banyak larangan untuk perempuan. Ini menjadi kasus budaya dalam tinjauan gender terutama dalam kedekatannya dengan problem kesetaraan dan pengarusutamaan gender. Dalam tulisan ini akan ditunjukkan beberapa 
contoh data dari tradisi lisan Nusantara tentang pantang larang untuk para perempuan terutama yang diberlakukan bagi para gadis untuk beberapa daerah, terutama pantang larang yang ada di pulau Jawa.

\section{Metode Penelitian}

Penelitian yang dikaji dan dikemukakan dalam tulisan ini adalah hasil analisis wacana yang berparadigma penelitian kualitatif, yang digali, dijelaskan, dan disampaikan melalui metode deskriptif dengan mendasarkan sumber data lisan yang sudah ditranskripsi dan didokumentasi dalam bentuk hasil unduhan dokumen tertulis di internet dengan validasi lisan pada ahli sastra Nusantara, folklor, sastra lisan dan komunitas adat di Jawa dan Bali serta beberapa informan dari berbagai daerah di Indonesia, misalnya komunitas adat Kalimantan atau Dayak, komunitas adat Sumba, komunitas adat Flores, komunitas adat Madura, komunitas adat Papua dan komunitas adat Ambon. Analisis data dilakukan secara kualitatif dengan prosedur analisis data interaktif.

\section{Pembahasan}

Pamali atau pantangan adalah hal-hal yang sering didengar dari orang tua masingmasing individu atau kakek/nenek tiap individu tersebut. Pantangan tersebut tentunya berawal dari banyaknya kasus yang terjadi karena melanggar pantangan tersebut meski segala sesuatunya adalah bersandarkan atas kehendak Tuhan. Penulis atau transkriptor pantang larang sering membubuhi komentar atau ungkapan "Percaya atau tidak, terserah bagaimana Anda menyikapinya?" Memang pada umumnya, pantang larang bergeser dari nilai percaya ke nilai rasional, bahkan kembali ke fungsionalitas.

Dalam budaya patriarki, perempuan mendapatkan banyak peraturan. Bahkan peraturan-peraturan yang dikenakan kepada kaum hawa ini sering tidak dapat dirasionalkan secara langsung. Oleh karena itu, larangan-larangan atau hal-hal yang ditabukan itu dikemas dalam wacana yang bernilai tabu, pembatasan, dan pematuhan kepada perempuan, sementara dianggap sebagai subordinat dari laki-laki atau subalter dari kekuasaan lakilaki. Berikut sejumlah contoh dan penjelasan pantang larang yang ditujukan kepada perempuan, terutama anak perempuan, anak perawan atau anak gadis di beberapa wilayah di Indonesia.

(1) Berpindah tempat pada waktu makan. Janganlah berpindah tempat pada waktu makan, karena kelak berakibat akan mendapat ibu tiri. Terkecuali pindah pada posisi yang lebih bagus misalnya semula makannya dilantai, kemudian pindah kemeja makan yang semestinya, kalau itu yang dilakukan kelak akan cepat mendapat pekerjaan yang lebih baik.

(2) Berselimut dengan tikar. Janganlah anda berselimut dengan tikar karena kelak anda akan digulung oleh ombak jika mandi di laut.

(3) Berteriak-teriak mengucapkan kata-kata kotor dalam hutan. Janganlah anda berteriak-teriak berkata-kata kotor pada saat berada di dalam hutan, karena anda tak lama lagi akan dimasuki roh halus jahat yang menguasai diri anda (kesurupan).

(4) Berfoto bersama dalam jumlah ganjil. Janganlah berfoto dalam jumlah ganjil karena salah satu dari yang difoto akan cepat meninggal. Biasanya yang ditengah.

(5) Bangun tidur terlalu siang..Jika anda bangun tidur terlalu siang hingga matahari hampir berdiri, akan berakibat segala bentuk rezeki yang akan datang akan selalu menjauh kembali.

(6) Bersin sewaktu akan bepergian.Anda tidak dapat langsung berpergian baik menggunakan kendaraan atau tidak setelah bersin. Paling tidak anda menunggu beberapa menit setelah bersin lalu boleh pergi, karena kalau 
anda bersin langsung pergi anda akan celaka diperjalanan.

(7) Berlama-lama dikamar mandi.. Janganlah anda berlama-lama dikamar mandi karena akan terlihat lebih tua dari usia anda sebenarnya.

(8) Duduk dipintu. Anda dilarang duduk tepat didepan pintu, karena khawatirkan ada makhluk lewat yang melewati pintu tersebut dan anda akan jatuh sakit.

(9) Gadis keramas dihari Sabtu.Jika anda seorang gadis, janganlah anda keramas pada hari Sabtu, karena berakibat anda akan mempunyai suami penyiksa

(10) Kebiasaan bersedih pada waktu hamil. Janganlah selalu bersedih pada waktu hamil, karena kelak akan mendapatkan anak yang cengeng.

(11) Kebiasaan duduk di tengah pintu waktu turun hujan lebat. Janganlah anda duduk ditengah pintu waktu turun hujan lebat karena suatu ketika anda dapat tersambar petir (yang sebenarnya petir tersebut, konon, mengincar setan).

(12) Kebiasaan makan asinan di malam hari. Janganlah anda terbiasa makan asinan di malam hari, karena akan selalu tertimpa keresahan hati, jika ia seorang yang belum menikah akan sulit jodoh, dan jika sudah menikah ia akan sering bertengkar.

(13) Kebiasaan mengetuk ujung rokok yang akan disulut kebenda keras. Janganlah melakukan Kebiasaan mengetuk ujung rokok yang akan disulut kebenda keras, karena kelak akan selalu mengalami kekecewaan karena gagal dalam karir dan rumah tangga.

(14) Kebiasaan menggigit bibir sebelah bawah. Janganlah anda selalu menggigit bibir sebelah bawah, karena kelak anda akan bernasib buruk dan rezeki seret.

(15) Kebiasaan menggigit bibir sebelah atas. Janganlah menggigit bibir sebelah atas karena akan selalu banyak hutang dalam hidup
(16) Kebiasaan menggigit kuku. Janganlah sering menggigit kuku, karena akan mengundang nasib buruk dan pembawaan sering gugup juga akan menderita batin.

(17) Kebiasaan memutir rambut.Janganlah anda memutir-mutir rambut karena kelak anda akan menjadi bahan gunjingan orang dan menjadi korban fitnah.

(18) Kebiasaan pura-pura menangis. Janganlah berpura-pura menangis karena akan berakibat orang tua akan menerima musibah.

(19) Kebiasaan bersiul di waktu malam. Janganlah anda selalu bersiul diwaktu karena disaat anda tidur dimalam itu dan akan mendengar siulan yang berasal dari luar kamar anda itu adalah ulah dari makhluk halus yang merasa terganggu dengan siulan anda dan membalasnya.

(20) Kebiasaan bersiul didalam rumah Janganlah anda selalu bersiul didalam rumah, karena akan mengundang makhluk halus yang akan berbuat jahat.

(21) Kebiasaan memberi saputangan kepada kekasih Janganlah mempunyai kebiasaan memberi saputangan kepada kekasih karena kan berakibat perpisahan tiada sebab.

(22) Kebiasaan membuang nasi sisa makan, karena masih kenyang.Janganlah selalu membuang nasi sisa makan, karena masih kenyang bermakna kelak selama satu tahun akan mengalami bentrokan keluarga yang beruntun.

(23) Kebiasaan makan pakai mangkuk Janganlah anda selalu suka makan pakai mangkuk, karena akan sering ditinggal pergi saudara.

(24) Kebiasaan mengusap muka/wajah dengan baju.Janganlah selalu mengusap muka/wajah dengan baju karena akan selalu dibenci orang dan susah rezeki.

(25) Kebiasaan memakai baju sambil berjalan.Janganlah suka, sering memakai 
baju sambil berjalan, karena akan berakibat cita-cita tidak akan terlaksana.

(26) Kebiasaan menyiksa anak perempuan. sudah menikah ia akan selalu disakiti dan disiksa oleh suaminya.

(27) Kebiasaan bernyanyi atau besiul pada waktu sedang makan.Janganlah anda selalu bersiul bila sendang makan karena anda akan mengalami kegagalan dalam usaha.

(28) Kebiasaan memukul anak wanita pada pantat (bokong). Janganlah anda selalu memukul anak wanita pada pantat (bokong), karena kelak anak tersebut akan menjadi hyper sex, dan bila sudah berumah tangga akan selalu ribut dengan suaminya.

(29) Kebiasaan mencabuti bulu alis mata. Janganlah suka mecabuti alis mata (khususnya wanita) karena akan menyebabkan ketidak nyamanan pada saat berhubungan intim.

(30) Kebiasaan memeluk kepala dengan kedua tangan. Janganlah anda melakukan kebiasaan memeluk kepala dengan kedua tangan karena akan menjadikan diri anda kehilangan akal dan pikiran menjadi buntu, meneketehe dan dungu.

(31) Kebiasaan memeluk lutut sambil berjongkok. Janganlah terbiasa memeluk lutut sambil berjongkok, karena akan berakibat selalu meneketehe pada saat menghadapi masalah dan putus asa.

(32) Memotong Kuku menurut hari. Janganlah memotong kuku pada hari Minggu, karena akan mendapat bencana, demikian juga pada hari Senin, karena akan ada orang yang dengki atau irihati, selain itu hari Sabtu juga termasuk hari yang kurang baik untuk memotong kuku karena akan mendatangkan halangan atau rintangan bagi anda. Disarankan untuk memotong kuku pada hari Selasa karena akan disukai orang banyak. Hari Rabu juga termasuk hari baik karena akan membawa keselamatan dan perlindungan dari Tuhan. Hari baik yang disarankan adalah hari Kamis anda akan mendapat rezeki. Terakhir hari yang disarankan membawa kebaikan adalah hari Jum'at karena akan membuat anda disukai dan dicintai orang.

(33) Mengangkat kaki. Pada aat bertiduran (tengkurap)/melakukan kaki keatas keduanya atau satu saja, bertanda bahwa anda menginginkan menginginkan sesuatu yang buruk terjadi pada ibu anda.

(34) Membuka payung. Anda dilarang membuka payung didalam rumah, karena akan terjadi sesuatu yang buruk dikeluarga anda.

(35) Menggunting kuku malam hari. Janganlah anda menggunting kuku pada mari, karena akan membuat usia anda lebih singkat.

(36) Menyapu di malam hari. Janganlah anda menyapu dimalam hari karena akan sulit untuk mencari rezeki.

(37) Menjahit kancing baju ketika baju masih dipakai. Janganlah menjahit kancing baju ketika ketika baju masih dipakai karena akan menderita penyakit yang parah dan selalu gagal dalam usaha selama 1 bulan.

(38) Menyisir rambut sambil berjalan. Janganlah adan menyisir rambut sambil berjalan, karena anda akan mendapat malu di depan umum.

(39) Mandi disiang hari bolong. Janganlah mandi disiang hari bolong, karena berakibat anda akan cepat tua.

(40) Makan nasi menggunakan piring kecil. Janganlah anda Makan nasi menggunakan piring kecil, karena akan berakibat selama hidup akan tersisih dari keluarga.

(41) Makan disudut meja.Janganlah anda makan disudut meja, karena akan berakibat kelak anda akan dimusuhi mertua dan perkimpoiannya akan hancur. 
(42) Makan otak binatang.Janganlah anda memakan otak binatang khususnya untuk anak kecil, karena akan menimbulkan uban sebelum waktunya.

(43) Makan dicobek atau lumpang.Janganlah anda makan dicobek atau lumpang, karena akan berakibat kelak anda akan dimusuhi mertua tanpa sebab.

(44) Makan di daun yang dilipat.Janganlah Makan didaun yang dilipat, karena akan berakibat kelak kehidupan keluarga anda tidak akan harmonis.

(45) Makan selalu dengan tangan tanpa sendok.Janganlah anda makan selalu dengan tangan tanpa sendok, kelak barakibat kehidupan anda menderita, bila ia seorang wanita akan menderita kanker rahim.

(46) Makan didepan pintu.Janganlah anda makan didepan pintu, kelak akan berakibat sulit mendapat jodoh.

(47) Makan telur ikan terlalu banyak. Janganlah makan terlalu banyak telur ikan khususnya untuk anak kecil, karena kelak akan berakibat terjangkit penyakit cacar yang membuat muka bopeng.

(48) Mengeluarkan suara ketika makan. Janganlah anda mengeluarkan suara ketika sedang makan, karena akan berakibat menjadi bahan gunjingan orang lain, atau menjadi pengundang binatang buas.

(49) Makan buah pisang (jantung).Janganlah makan buah pisang (jantungnya) khususnya anak kecil, karena kelak akan berakibat sianak akan bodoh, dungu, dan bloon.

(50) Makan masakan kaki ayam.Janganlah makan masakan kaki ayam khususnya anak kecil, karena kelak tulisannya akan jelek seperti cakar ayam.

(51) Makan pisang yang berada di posisi pinggir (dalam satu sisir pisang). Janganlah anda memakan pisang yang berada disisi pinggiran pada sisiran pisang, karena akan mendapat sikap selalu disisikan dalam setiap pergaulan.
(52) Makan sirih bagi wanita muda.Jika anda adalah wanita janganlah anda bersirih (makan sirih), karena kelak akan berakibat saat hari pernikahan kelak akan mengalami haid/menstruasi.

(53) Menjual cuka asam pada malam hari.Janganlah anda menjual cuka asam pada malam hari, karena akan berakibat pelanggan anda akan berkurang, dan selalu betengkar dengan tetangga.

(54) Menjual silet dan jarum pada malam hari.Janganlah anda menjual silet dan jarum pada malam hari, karena akan berakibat toko, usaha anda akan bangkrut.

(55) Menjual garam pada malam hari .Janganlah anda menjual garam pada malam hari, karena akan membawa kebangkrutan pada toko, warung, usaha anda.

(56) Menyalakan rokok bersumber api (yang sedang membuat senjata tajam).Jangan menyalakan rokok bersumber api dari bara besi yang sedang membuat senjata tajam, karena setelah jadi senjata tajam ia akan segera memakan korban jiwa.

(57) Memakai payung dalam rumah. Janganlah memakai payung dalam rumah karena akan selalu kesukaran dalam hidup.

(58) Malas menghadiri undangan perkawinan. Janganlah sering tak menghadiri undangan perkawinan karena akan membuat anda sulit jodoh.

(59) Makan sebelum orang tua makan. Janganlah mendahului makan sebelum orang tua makan, karena akan menjadikan sulit untuk mendapat rezeki

(60) Memotong rambut malam hari di rumah.Janganlah suka memotong rambut dimalam hari di rumah, karena berakitbat anda akan didatangi makhluk halus jahat dalam mimpi.

(61) Tidur disore hari menjelang magrib Janganlah anda tidur disore hari menjelang magrib, karena kelak anda akan menjadi orang tak bermalu (gila). 
(62) Tidur terlentang dengan tangan dikepala.Janganlah anda tidur terlentang dengan tangan menindih kening kepala anda, karena secara tidak langsung akan menyumpahi orang tua anda untuk pergi untuk selama-lamanya.

(63) Wanita muda makan masakan tunggir ayam.Jika anda seorang wanita muda/ belum bersuami hendaknya jangan memakan tunggir ayam, karena kelak anda akan mendapatkan suami yang tidak setia dan selalu makan hati.

(64) Membersihkan telinga dimalam hari .Janganlah anda membersihkan telinga dimalam hari, karena akan membawa anda kedalam kesulitan rezeki.

(65) Membuang puntung rokok yang masih panjang.Jangan membuang puntung rokok yang masih panjang, karena akan menjadikan ada akan kesulitan rezeki.

(66) Mandi dipantai dengan pakaian warna merah atau hijau tua.Janganlah sering, selalu memakai pakaian warna merah atau hijau dipantai karena suatu saat kelak akan dijadikan mempelai wanita atau pria oleh makhluk halus.

(67) Para gadis atau perjaka biasa membeli barang bekas.Jika ada gadis atau perjaka biasa membeli barang bekas kelak suatu saat akan menikah dengan janda atau duda.

(68) Jangan anda tidur dengan posisi kepala ada di sebelah utara dan kaki di sebelah selatan, karena anda akan cepat meninggal (posisi mayat yang dikubur).

Keenampuluh sembilan contoh data pantang larang di atas adalah contoh data yang tersebar dari berbagai etnis di Indonesia. Sebagian besar pantang larang berlaku untuk perempuan, walaupun ada juga yang berlaku umum. Hal itu menunjukan bahwa perempuan Indonesia dalam ikatan budaya patriarki diikat dalam tata norma, etika, sebagai acuan moral untuk mereka secara tradisional sehingga tidak mudah menjalankan hidup. Namun demikian, sekarang sudah berubah. Tidak semuanya masih dipatuhi secara adat. Sebagai dokumen tradisi lisan, pantang larang ini tetap dijadikan sesuatu yang perlu mendapatkan kajian lebih pas dalam bentuk penjelasan kearifan lokal.

\section{Penutup}

Pamali atau pantangan adalah hal-hal yang sering didengar dari orang tua kita atau kakek/nenek atau orang tedahulu sebagai fenomena bahasa, yang terpola, dan disikapi sebagai tradisi lisan bahkan menjadi salah satu kajian sastra lisan. Dalam konteks kajian gender, pantang larang yang banyak diperuntukkan bagi perempuan menunjukkan adanya fenomena budaya patriarki yang sangat membatasi kaum perempuan di sejumlah etnis di Indonesia. Walaupun demikian, dokumen pantang larang merupakan dokumen yang perlu diinventarisasi dengan baik sebagai bentuk bahan kajian dalam kajian tradisi lisan, sastra lisan, dan kajian budaya Indonesia terutama keberadaannya dalam konteks budaya daerah dengan penjelasan yang lebih memadai, dan kemungkinan transformasi nilai dari hal-hal yang bersifat tabu ke hal-hal yang bersifat ilmiah. Dalam konteks kajian sastra, kajian pantang larang Nusantara menjadi bahan kajian sastra interdisipliner, terutama dalam kaitannya dengan komunitas adat, masyarakat mitis, dan pendekatan antropologi sosial, atau antropologi komunikasi.

\section{Daftar Rujukan}

Amir, Andriyeti.2013. Sastra Lisan Indonesia. Yogyakarta: Andi Offset

Kumpulan Pamali yang Ada di Indonesia.

Online: http://menujuhijau.blogspot.com

/2012/06/kumpulan-pamali-yang-ada-diindonesia.html\#ixzz2lpk8jqnZ. Diunduh 15 November 2013

Ningsih, Sri. Pantang Larang dan Pemaknaannya.Makalah. disampaikan dalam seminar nasional di FKIP Universitas Negeri Jember 11 November 2013 